\title{
Equal Pay and Comparable Worth: Conceptual and Functional Bearings to Closing Nigeria's Gender Pay Gap
}

\author{
Chineze Sophia Ibekwe, $\mathrm{PhD}$ * \\ Faculty of Law, Nnamdi Azikiwe University, PO Box 5025, Awka Anambra State, Nigeria
}

\begin{abstract}
Occupational segregation by sex and the systemic undervaluation of jobs held by women are historic forms of labor market discrimination which lie at the root of sustained inequality at work. which in turn fuels the gender pay gap. Equal pay for equal work is the labour rights concept that individuals doing the same work should receive the same remuneration irrespective of individual or group characteristic such as gender which are unrelated to ability and performance. The doctrine of comparable worth is an attempt to alleviate the inequities caused by sexsegregated jobs and disparate pay scales for 'female' and 'male' dominated jobs. Adopting the doctrinal method, this work attempts to evaluate the functional relevance of Equal Pay and Comparable Worth Concepts to Nigerian labour law and practice. The work finds that although there is a severe paucity of equal pay legislation in Nigeria, the National Industrial Court is empowered by the Constitution to enforce international best practices in labour law. However, it is the historical perception of women as care-givers rather than a paucity of laws or a lack of education that most critically hinders women from attaining wage parity in the public and private employment sectors. It is recommended that Nigeria incorporates the ILO anti-discrimination Conventions into her labour laws whilst also pursuing socio-economic reforms across all stages of life to upturn the deep-seated biases and inequities against women in the world of work.
\end{abstract}

Keywords: comparable worth, equal pay, gender pay gap, women as care-givers, employment equity, Nigeria labour law.

DOI: $10.7176 / \mathrm{JLPG} / 100-04$

Publication date:August $31^{\text {st }} 2020$

\section{Introduction}

The concept of Equal Pay for Equal Work is one which has been entrenched in International Law since the creation of the International Labour Organisation (ILO) in 1919. ${ }^{1}$ Equal pay for equal work was one of the founding principles of the ILO and is recurrent among international human rights instruments, for example Article 7 of the International Covenant on Economic, Social and Cultural Rights ${ }^{2}$ and the Article 15 of African Charter on Human and Peoples' Rights. ${ }^{3}$ Several nation states have enacted laws specifically to enforce it ${ }^{4}$ or make reference to the equal pay principle via provisions in other laws. ${ }^{5}$ Equal pay for equal work is the labour rights concept that individuals doing the same work should receive the same remuneration. ${ }^{6}$ Age, race, sex, religion, ethnic origin, political association or any other individual or group characteristic unrelated to ability and performance should not determine who earns more. The equal pay principle is most commonly used in the context of sex/gender discrimination as equal pay for women but it encompasses every situation in which work effort in unequally rewarded. It can be applied in cases of casualisation of labour (contract staff), indigene salary versus expatriate salary dichotomy, health-related discrimination such as disability, HIV status and even age discrimination.

This research focuses on equal pay in the context of gender discrimination in which case it means that an employer should not pay one employee at a rate of pay less than another employee on the basis of sex when they perform substantially the same kind of work in the same establishment provided that their work requires substantially the same skill, effort and responsibility and is performed under similar working conditions. ${ }^{7}$ The payment here encompasses the full range of wages and benefits accruing to employees including basic pay, nonsalary payments, bonuses, allowances, etc. Unfortunately, all over the world, women working in the same occupation as men are systematically paid less, even if their educational levels equal or exceed those of their male counterparts. ${ }^{8}$

\footnotetext{
${ }^{1}$ Creation of the ILO was part of the Treaty of Versailles which brought and an end the First World War in 1918

${ }^{2}$ Article 7, International Covenant on Economic, Social and Cultural Rights,

${ }^{3}$ Article 15 African Charter on Human and Peoples' Rights,

${ }^{4}$ In the United States for example, the law states that 'employers may not pay unequal wages to men and women who perform jobs that require substantially equal skill, effort and responsibility, and that are performed under similar working conditions within the same establishment, U.S. Equal Employment Opportunity Commission.

${ }^{5}$ Section 17(3)(e) of the Nigerian 1999 Constitution enshrines the principle of equal pay for equal work.

${ }^{6}$ European Institute for Gender Equality, “Equal Pay for Equal Work,” https://eurogender.eige.europa.eu/posts/equal-pay-equal-work, accessed July 24, 2020.

${ }^{7}$ Ontario Ministry of Labour, Training and Skills Development, 'Equal Pay for Equal Work' https://www.ontario.ca/document/your-guideemployment-standards-act-0/equal-pay-equal-work, accessed 22 July 2020.

${ }^{8}$ The gender wage gap is still an average of 20 per cent (18.8 per cent) throughout the world. ILO, (2019), A Quantum Leap for Gender
} 


\subsection{Comparable Worth and Pay Equity}

Even though equal pay for equal work is eminently fair in concept, not all work is equal because different jobs have different requirements, some more onerous than others. Comparable worth is the economic terminology for 'equal pay for work of equal value' or 'equal remuneration for work of comparable worth.' ${ }^{1}$ Whereas 'equal pay for equal work' limits the application of the equal pay principle to work undertaken by two individuals in the same area of activity and in the same enterprise, the concept of equal remuneration for work of equal value is broader and encompasses cases where men and women do different work. In order to determine whether different types of work have the same value, they can be assessed through a job evaluation method. ${ }^{2}$ The doctrine of comparable worth is an attempt to remedy the inequities of pay which result from a long history of sex-segregated jobs and different pay scales for 'female' and 'male' jobs. Comparable worth seeks to achieve pay equity - a term which comprises the various approaches and methods adopted to achieve equity and justice in wages. ${ }^{3}$

Historically, jobs in which workers are primarily women have been systematically undervalued compared with equivalent jobs held by majority men. This history of undervaluation has decreased the wages in jobs done by women relative to the wages for jobs performed by men. Comparable worth systems seek to compensate jobs held primarily by women or men more equitably by comparing the educational and skill requirements, task activities, and responsibility in different jobs, and attempting to compensate each job in relation to such factors rather than the traditional pay history of the jobs. Thus, the job of a licensed practical nurse (held mostly by women) might compare more equally to the job of an electrician (held mostly by men), and compensation adjusted accordingly. ${ }^{4}$ Other examples of the jobs that have been compared in the context of evaluating equal pay for work of equal value include: caterers and cleaners (mostly women) with gardeners and drivers (mostly men); social affairs managers (mostly women) with engineers (mostly men); and flight attendants (mostly women) with pilots and mechanics (mostly men). ${ }^{5}$ Most comparable worth agreements have been the result of governmental policy intervention or labour union negotiations and are more likely to be found in the public sector than the private sector. ${ }^{6}$ The approach lends itself better to large organizations, whether public or private, and has little effect on such jobs as domestic workers, where few people work in each workplace.

Free market advocates argue that government actions to correct gender pay disparity serves to interfere with the system of voluntary exchange in employment. The employer and employee 'negotiate' the terms of employment but it is the employer who ultimately decides how much is paid according to the value the employee adds to the employer's business, not according to a prevailing government policy. ${ }^{7}$ A private business would not want to lose its best performers by compensating them less and can ill afford paying its lower performers higher because the overall productivity will decline ${ }^{8}$ In most actual implementations of comparable worth however, the pay of the lower-paid group is adjusted upwards, and the pay of the higher-paid group is allowed to grow more slowly than it would have without the comparable worth system in place. ${ }^{9}$

It is also argued that from an economic standpoint, requiring comparable worth wage increase for predominantly female jobs is akin to levying a tax on employers then paying the revenues raised from the tax to those employees instead of into the Government treasury. ${ }^{10}$ This makes it more expensive to employ predominantly female labor. Some workers in predominantly female jobs will enjoy higher wages but other workers, both in predominantly female jobs and in other (e.g., predominantly male or 'integrated') jobs may lose their jobs or remain unemployed. Insofar as comparable worth requires wage increases for certain jobs but abhors wage cuts or reduction in other employee benefits, it will entail higher cost of goods/services (in the private sector) or higher taxes and/or reductions in other programs (in the public sector). ${ }^{11}$ Thus, there will be both winners and losers from comparable worth wage increases.

\subsection{The Gender Pay Gap}

It is a well-established fact that 'male' jobs are traditionally compensated more highly in part because they are

Equality: for a Better Future of Work for All, (Geneva: ILO).

Encyclopedia.com, https://www.encyclopedia.com/social-sciences-and-law/economics-business-and-labor/economics-terms-andconcepts/comparable-worth, assessed July 222020

${ }^{2}$ ILO, Equal Remuneration for Work of Equal Value, https://www.ilo.org/global/topics/wages/minimum-wages/rates/WCMS 433906/lang-en/index.htm, accessed July 24, 2020.

${ }^{3}$ Op cit

${ }^{4}$ Lewis, J.J., (2020) "Comparable Worth: Equal Pay for Work of Equal Value." ThoughtCo, Feb. 11, 2020, thoughtco.com/comparable-worthpay-equity-3529471. accessed on 26/10/20

${ }_{6}^{5}$ ILO, Equal Remuneration for Work of Equal Value, ibid.

${ }^{6}$ Killingsworth, M.R., (1990), The Economics of Comparable Worth. Kalamazoo, MI: W.E. Upjohn Institute for Employment Research.

7 Tennant M., (2009) ‘The Justice of Pay Discrimination', www.LewRockwell.com, accessed on 26/7/20.

${ }^{8}$ Ibid.

${ }^{9}$ ILO, (2013), Equal Pay, an Introductory Guide, https://www.ilo.org/global/publications/WCMS 216695/lang--en/index.htm, assessed July 22, 2020.

${ }^{10}$ Killingsworth, ibid.

${ }^{11}$ Ibid. 
held by men, and the 'female' jobs are compensated less well in part because they are held by women. ${ }^{1}$ It is these twin factors of unequal pay and gender pay discrimination that have led to the global phenomenon of the gender pay gap. Gender pay gap (GPG) has to do with the relative differences in the average gross earnings of men and women within an economy. ${ }^{2}$ It is measured as the difference in the average hourly wage of all men and women across the workforce. This means that even if there are more women than men in less well-paid jobs within an organization and more men in the better paid jobs, the GPG will be wider. ${ }^{3}$ More women than ever before are being employed overall, yet they continue to be overrepresented in low paid, part-time and insecure employment.

Free market supporters believe that any legislation supporting equal pay for equal work does in fact harm the very groups the legislation aims to protect. ${ }^{4}$ It is argued that a free market compels discriminative employers to pay for their prejudice whereas an equal pay for equal work legislation would simply allow those same employers to have no consequence for their prejudice. ${ }^{5}$ An employer who holds an unfair prejudice against women will always hire the man, given the requirement to pay both equally. However, if the woman offers to be compensated slightly less than the man despite having equal talents, the employer will have to pay for the prejudice by still hiring the man. In this case, a competitor now has access to an employee who is both equally skilled and willing to work for less, which will thus put the discriminating employer at a competitive disadvantage ${ }^{6}$ Economists expect that in free market capitalist economy, managers should be eager to hire less costly women workers, thereby making the wage gap disappear. ${ }^{7}$ This expectation has not panned out. Understanding why women continue to outnumber men in less well-paid roles is therefore key to closing the GPG. ${ }^{8}$

\section{The Gender Pay Gap and Anti-Discrimination Law in Nigeria's Employment Sector.}

The right of women to work, without any form of discrimination, is recognized and guaranteed by many international and national instruments: Article 2 of CEDAW, Section 18 (3) African Charter on Human and Peoples Rights; Article 7 of ICESCR, ILO Equal Remuneration Convention of 1951 Discrimination Convention (Employment and Occupation) 1958 (No 111), Workers, with Family Responsibilities Convention 1981 (No 156) and Maternity Protection Convention, 2000 (No 183), and Section 42 of the Nigerian 1999 Constitution to mention a few. These legislations demand the elimination of gender inequality in the workplace, whether in the choice of profession, availability of employment opportunities, in the right to promotion to senior management levels, in equal remuneration, and job security. ${ }^{9}$ Despite Nigeria's ratification of these instruments, gender-based discriminations in the Nigerian labour market persist practically everywhere, and at all levels. The higher the position in an organization or company the more glaring is the gender gap. The reality in Nigeria today is that legal, cultural and social obstacles still impede the right of women to work and the parity of their earnings with their male counterparts. ${ }^{10}$

These obstacles and discriminatory practices are best explained through the subsisting laws regulating some jobs in the country. A typical example is Section 55 and 56 of the Labour which prohibit women from working at night (excluding nurses and management cadre) and from working underground in mines. ${ }^{11}$ Section 53 of the Labour Act also protects the right of women to paid maternity leave. But in Ajiboye v Dresser Nig. Ltd, ${ }^{12}$ the Court held that the termination of a female employee's appointment a day before she was due back from maternity leaves to be valid. This is despite previous judgements upholding the right to maternity leave. ${ }^{13}$ The sections are discriminatory to the extent that they limit women's access to work yet the International Equal Remuneration Convention of 1951 calls for equal job opportunities for men and women. Taxation of women in the public sector is still based on the premise that married women have no family responsibilities and are maintained by men. In cases that both men and women work, men are entitled to tax relief for children and dependents, whereas women

\footnotetext{
${ }^{1}$ Fernandez A., (2015) Humanity Divided: Confronting Inequality in Developing Countries, UNDP 2015.

${ }^{2}$ UNDP, (2010) Human Development Report 1995, (New York: Oxford University Press).

${ }^{3}$ De Henau, et al, (2018) Women, Employment and Earnings (WBG Briefing: 2018); United Kingdom Government Equalities Office.

${ }^{4}$ Becker G, (1975) The Economics of Discrimination, (Chicago: University of Chicago Press, 1957), p.27

${ }^{5}$ Ibid.

${ }^{6}$ Henderson D.R., (2008) ‘How Free Markets Break Down Discrimination’ The Freeman, Vol. 58, Issue 3, April 2008.

${ }^{7}$ Farrel W., (2006) 'Are Women Earning More Than Men?' Forbes Newspaper, May 12, 2006, www.forbes.com/2006, accessed on 26/07/20.

${ }^{8}$ Jones L., (2019) “Women's Progression in the Workplace”, Global Institute for Women's Leadership, (London: Kings College).

${ }^{9}$ Ifemeje S.C. and Ikpeze O.V.C., (2012) “Global Trend Towards Gender Equality: Nigeria's Experience in Focus" Vol. 2, No.3 Kuwait Chapter of Arabian Journal of Business and Management Review, 51

${ }^{10}$ Ibid.

${ }^{11}$ Labour Act Cap L1 LFN 2004, Section 55(1) provides that: "No woman shall be employed in night work in a public or private industrial undertaking or any branch thereof or any agricultural undertaking or any branch thereof". The aforementioned provision does not apply to women employed as nurses or holding responsible positions on management who are not ordinarily engaged in manual labour (Section 55 (2) of Labour Act). Similarly, Section 56(1) excludes women from being employed on underground works in any mine. It is our position that the discriminatory laws enumerated herein should be expunged from the statute books, because they do not serve any useful purpose. 1233 [1974] CCHCJ 167

${ }^{13}$ For example, in Okunbowa v Group Consultant Nigeria \& 2 Ors [1972] CCHCJ 57, the female worker's employers denied her right to maternity leave and threatened that if she proceeded stayed away from work after having a baby, it would be treated as a breach of contract. She nonetheless went on maternity leave and was sacked. The Court held the termination of her appointment to a breach of the Labour Act.
} 
are not because men are automatically defined as bread winners. ${ }^{1}$

There is a plethora of gender-discriminatory laws in the Nigerian armed forces. For instance, section 118 of the Nigeria Police Regulation ${ }^{2}$ provides that a female seeking employment into the Nigerian police force must be unmarried before she can be eligible for enlistment and must remain unmarried for at least three years after entering the force. ${ }^{3}$ Male police officer are not subjected to the same restrictions. Police women married to civilian husbands are disallowed from living in police barracks; Travel allowance made only for accompanying 'wife' and children - no husbands; provision for payment of disability compensation, pensions and gratuities refer only to 'wife' or 'widow' instead of spouse; women police officers as a general rule, are to be posted on duties which are concerned with women and children. ${ }^{4}$ Section 124 provides that a woman police officer desirous of marrying must apply in writing to the Commissioner of Police of her command with the fiancée's bio data. Permission may be granted if the Fiancée is adjudged to be of good character. Section 127 of the same regulation provides that an unmarried Police Officer who is pregnant shall be discharged from the force and shall not be re-enlisted except with the permission of the Inspector General of Police.

Opportunely, in a suit filed by the Women Empowerment and Legal Aid Initiative (WELA), the Federal High Court sitting in Lagos in May 2012 declared illegal and unconstitutional the provision of the Regulation 124 as being inconsistent with section 42 of the Constitution and Article 2 of the African Charter on Human and Peoples' Rights which prohibit discrimination on the basis of sex. ${ }^{5}$ Employees of other government agencies and civil liberties organizations, inspired by the Police Act ruling began to submit discriminatory employment policies to court for interpretation. An instance is the action filed in September 2012 before the Federal High Court, Lagos by the Legal Defence Assistance Project (LEPAD) -a non-governmental organisation, against the Nigeria Drug Law Enforcement Agency (NDLEA) for alleged employment discrimination against women. ${ }^{6}$ As in the police force, women seeking employment in the NDLEA were required to be unmarried, a requirement their male counterparts were not expected to meet. Also, women already employed had to remain unmarried for at least two years and must seek the management's permission whenever they intend to get married. ${ }^{7}$

It is important to reiterate here that, despite her ratification of the above-mentioned ILO Conventions, Nigerian institutions do not sufficiently protect the citizens from discrimination in the workplace as such; incidents of inequality and discrimination are myriad, multifarious and multidimensional. In over 90 per cent of sub-Saharan African countries, more women work in the informal employment sector than men. ${ }^{8}$ Not only are women more likely to work informally than men, they are also often found in occupations that are the most vulnerable to decent work deficits, such as in domestic, home-based or contributing family work. ${ }^{9}$ It is therefore not surprising that in most of these countries more women than men who work in the informal economy live in households which are below the poverty line. ${ }^{10} 60-79 \%$ of the rural work force is women but men are five times more likely to own land. Without land title, it is hard for women to raise the finance they need to start productive enterprises. One in every five businesses is run by a woman but they are constrained by lack of capital and have to rely on savings. Despite being better educated than their male peers in the micro-enterprise sector, women are less likely to secure loans. ${ }^{11}$ Even women in the formal employment sector are paid less than men. Only one in every three employees in the privileged non-agricultural formal sector is a woman. Regardless of their educational qualifications, women earn consistently less than their male counterparts. In some cases, they even earn less than men with lower qualifications. ${ }^{12}$

\footnotetext{
1 'Access to Financial Services in Nigeria Survey, 2010' Enhancing Financial Innovation and Access (EFInA), http://www.efina.org.ng/mediacentre/news/access-to-financialservices-in-nigeria-survey-2010/, accessed 24/2/13.

${ }^{2}$ Made pursuant to the Police Act Cap P19 Law of Federation of Nigeria 2004, Section 118(9).

${ }^{3}$ In the same vein, section 124 provides that a woman police officer desirous of marrying must apply in writing to the Commissioner of Police of her command with the fiancée's bio data. Permission may be granted if the fiancée is adjudged to be of good character. Section 127 provides that an unmarried Police Officer who is pregnant shall be discharged from the force and shall not be re-enlisted except with the permission of the Inspector General of Police.

${ }^{4}$ Section 121 of the Police Regulations,

${ }^{5}$ Suraj L. (2012) 'Female Cops Can Now Marry without Permission' Sahara Reporters, http://saharareporters.com/news-page/nigerian-courtnullifies-police-marriage-permit-female-cops-can-now-marry-without-permission accessed November 28, 2012.

${ }^{6}$ Adesomoju A., (2012) 'LEPAD Sues NDLEA for Gender Discrimination', Punch Newspaper, http://www.punchng.com/news/ledap-suesndlea-for-gender-discrimination/, accessed October 29, 2012.

${ }^{7}$ Article 5 (1) and (2), Part II of the NDLEA Order, 2002 made pursuant to the NDLEA Act Cap N30 LFN 2004

${ }^{8}$ World Bank 2018

${ }^{9}$ Decent work has been defined by the ILO and endorsed by the international community as being productive work for women and men in conditions of freedom, equity, security and human dignity. Decent work involves opportunities for work that is productive and delivers a fair income; provides security in the workplace and social protection for workers and their families; offers better prospects for personal development and encourages social integration; gives people the freedom to express their concerns, to organize and to participate in decisions that affect their lives; and guarantees equal opportunities and equal treatment for all. See ILO: Toolkit for mainstreaming employment and decent work (Geneva, 2007).

10 Ibid.

${ }^{11}$ Microfinance Africa, (2010) 'Nigerian Women in Agro-Entrepreneurship: Development Issues and Challenges, Microfinance Africa, http://microfinanceafrica.net/news/nigerian-women-agroentrepreneurship-development-issues-and-challenges accessed 21/07/20.

${ }^{12}$ Program on the Global Demography of Aging (PGDA), (2010), "Nigeria: The Next Generation Report", PGDA Working Paper, No. 62,
} 


\subsection{The Major Cause Causes of the Gender Wage Gap in Nigeria}

The gender pay gap is a universal phenomenon and the factors which cause it are also universal although the relative importance of these factors varies by country and over time. In Nigeria, two major factors emerge: gender differences in education/training and historical attitudes towards the role of women as caregivers in society. There is massive improvement in the rate of girl-child enrollment in primary and secondary education. One can safely say that the gender gap in education has been significantly minimized and that the educational capability of women is undeniable. However, girls are still more likely than boys to leave school early, and when they leave, they often do not proceed to get jobs; rather, they most likely marry early. Also, girls are usually the first to be kept from school to do domestic work or care for sick relatives. At age 20, less than $4 \%$ of men are married, compared to about $50 \%$ of women in rural areas. ${ }^{1}$ With early marriage comes early pregnancies and household responsibilities that effectively remove women from labour market opportunities. Stereotyped assumptions, family and social pressures also tend to channel boys and girls, women and men, into different fields with women having a narrower range of education and training, most often in lower-earning opportunities like farming, domestic services, and other informal jobs.

Education is critical for increasing girls' opportunities and is one of the most powerful determinants of young women's avoidance of early marriage and childrearing. ${ }^{2}$ Though gaps persist, increased school enrollment, particularly at the primary level, has helped advance gender equality and women's empowerment. Yet schooling on its own, does not guarantee equality in the world of work. Stereotypical assumptions regarding women's place in society, their aspirations, capabilities and 'suitability' for certain jobs, have contributed to occupational sex segregation in the labour market. For many countries, significant educational achievements have not closed significant gender gaps in the workforce. In Qatar for instance, there are more than five women enrolled in higher education for every man, yet there are twice as many men as women in the labor force. ${ }^{3}$

In Nigeria, women are increasingly acquiring the education and skills required to secure better paying jobs but the societal perception of women as care-givers constantly holds them back. Globally, over 41.5 per cent (64\% in Africa) of adult women with a university degree are either unemployed or outside the labour force, while only 17.2 per cent of men are in a similar situation. Women and men are not getting comparable employment dividends for their education. ${ }^{4}$ Unpaid care work is the main reason why women are outside the labour force. Across the world, 606 million working age women (or 21.7 per cent) perform unpaid care work on a full-time basis, compared to 41 million men 50 (or 1.5 per cent). In Africa, the number drops slightly to 15.7 per cent. 5 The distribution of unpaid care work between men and women in the household influences women's levels and types of engagement in the labour market. Indeed, where the bulk of caregiving (for children, older persons, persons with disabilities and household chores) falls on women's shoulders, they are less likely to work for pay or profit. ${ }^{6}$

Therefore, while education is vital to the admittance and upward mobility of more women in paid employment, the imbalanced division of work within the household between men and women is one of the most resilient features of gender inequality and the gender pay gap. ${ }^{7}$ So far as social norms continue to reinforce the roles of women as caregivers and men as breadwinners, women will continue to be susceptible to low and unequal pay, violence and harassment at work, a disproportionate amount of stress as a result of working two shifts daily - one paid shift outside the home and another unpaid shift at home and poor representation in policy and decision-making.

At this juncture, it must be emphasized that caregiving is important work. It plays an enormous role in societal growth and is indispensable to human wellbeing development. Indeed, caring for children, spouses, parents or other dependent family members may sometimes be fulfilling for the care provider and is always beneficial for those who receive the care. Care should therefore be recognized as work worthy of remuneration in Nigeria. Labour laws, social policies and support services should be made available to protect care-givers, whether male or female. In a number of countries, women have decided not to have children for the simple reason that the sacrifice and loss of earning involved makes child-rearing an expensive and ill-appreciated life choice. Such countries experience declining population growth, an ageing population, insufficient workforce, necessary (though sometimes undesirable) mass immigration of foreigners which leads to the fear (rational or otherwise) of extinction. No matter where women work - classrooms, boardroom, online, or in the field, the care and paid work dilemma must be rectified before pay equity can be attained by narrowing the gender pay gap.

\footnotetext{
https://cdn1.sph.harvard.edu/wp-content/uploads/sites/1288/2013/10/PGDA WP 62.pdf accessed 24/7/20

${ }^{1}$ Enfield S, (2019) Gender Roles and Inequalities in the Nigerian Labour Market, (United Kingdom: Institute of Development Studies) May 2019.

2 Singh S. and Samara R., (1996) “Early Marriage Among Women in Developing Countries.” 22 (4) International Family Planning Perspectives: $148-175$.

${ }^{3}$ Hausman R. et al, The Global Gender Gap Index 2012 Report, (Davos: World Economic Forum, 2012), World Development Indicators, 2011 data.

${ }^{4}$ ILO, (2018) calculations based on ILOSTAT, in A Quantum Leap for Gender Equality, ibid

${ }^{5}$ Ibid.

${ }^{6}$ Ibid.

${ }^{7}$ ILO, A Quantum Leap for Gender Equality, Ibid.
} 


\section{Applying Comparable Worth to Create Fairer Wages}

The equal pay concept can be rather complex in its application. It is based on an analysis of the work which is done by employees or workers be they male or female. From the point of view of the employer, this approach does not necessarily make sense. The employer is interested nowadays not just in the content of the work performed but the manner in which that work is performed. The employer is interested in what the employee can bring to the job and how the employee can add value to the work which is performed. What is really needed in society is some rational basis to compare what sometimes are very different occupations and jobs, especially when this involves comparing 'men's and 'women's work'; 'skilled and unskilled work'; 'work integrated into the business and that which is ancillary'. Typically, the criteria used to compare dissimilar jobs evaluates work requirements as well as the investment individuals must make to attain these positions. In addition, the amount of skill and training required, the potential for danger and threat to one's life, the disagreeableness involved in the work, as well as the degree of responsibility associated with a job all figure prominently when making such calculations. ${ }^{1}$

The question is therefore, how do we implement comparable worth in the Nigerian workforce to ensure that male and female dominated jobs are remunerated fairly? To better appreciate the nuances of the enforcement challenges, let us use as an examples societies where equal pay has been more contentiously debated and rigorously enforced.

\subsection{Comparable Worth Calculation in the United States}

The Equal Pay Act was passed by the Federal Government of the United States in 1963 and made it illegal to pay men and women different wage rates for equal work on jobs that require equal skill, effort, and responsibility and are performed under similar working conditions. One year after passing the Equal Pay Act, Congress passed the 1964 Civil Rights Act. ${ }^{2}$ Title VII of this Act makes it unlawful to discriminate based on a person's race, religion, color, or sex. Title VII attacks sex discrimination more broadly than the Equal Pay Act extending not only to wages but to compensation, terms, conditions or privileges of employment. ${ }^{3}$ Thus, with the Equal Pay Act and Title VII, an employer cannot deny women equal pay for equal work; deny women transfers, promotions, or wage increases; manipulate job evaluations to relegate women's pay; or intentionally segregate men and women into jobs according to their gender. ${ }^{4}$

In seeking to achieve pay equity, a fundamental requirement of the Equal Pay Act is that the jobs being compared are 'equal.' The jobs need not be identical, but they must be substantially equal. It is job content, not job titles, that determines whether jobs are substantially equal. Therefore, differences in remuneration are permitted when there are objective differences in the value of the work to be performed. Specifically, the EPA necessitates a means of measuring and comparing different jobs on the basis of objective criteria such as skills, working conditions, responsibilities and effort. Where job evaluation based on objective criteria, free from stereotyped notions of the value of jobs typically undertaken by women or men, results in some jobs having different values from others, these differences should be reflected in levels of remuneration. Each of these factors is summarized below:

Skill: Measured by factors such as the experience, ability, education, and training required to perform the job. The issue is what skills are required for the job, not what skills the individual employees may have. For example, two bookkeeping jobs could be considered equal under the EPA even if one of the job holders has a master's degree in physics, since that degree would not be required for the job.

Effort: The amount of physical or mental exertion needed to perform the job. For example, suppose that men and women work side by side on a line assembling machine parts. The person at the end of the line must also lift the assembled product as he or she completes the work and place it on a board. That job requires more effort than the other assembly line jobs if the extra effort of lifting the assembled product off the line is substantial and is a regular part of the job. As a result, it would not be a violation to pay that person more, regardless of whether the job is held by a man or a woman.

Responsibility: The degree of accountability required in performing the job. For example, a salesperson who is delegated the duty of determining whether to accept customers' personal cheques has more responsibility than other salespeople. On the other hand, a minor difference in responsibility, such as turning out the lights at the end of the day, would not justify a pay differential.

Working Conditions: This encompasses two factors: (1) physical surroundings like temperature, fumes, and ventilation; and (2) workplace hazards.

Establishment: The prohibition against compensation discrimination under the EPA applies only to jobs within an establishment. An establishment is a distinct physical place of business rather than an entire business or

\footnotetext{
${ }^{1}$ Maclagan P., (1998), Management \& Morality, (Thousand Oaks, IL: Sage Press), p. 33

${ }^{2}$ Equal Pay Act of 1963, finduslaw.com; Civil Rights Act of 1964." 42 U.S.C. § 2000e-2000e-17

${ }^{3}$ Peterson T. and Morgan L.A., (1995) 'Separate and Unequal: Occupation-Establishment Sex Segregation and the Gender Wage Gap' American Journal of Sociology 101, 329-365, (Chicago: University of Chicago Press) https://www.jstor.org/stable/2782431, accessed 24/7/20. ${ }^{4}$ Ibid.
} 
enterprise consisting of several places of business. In some circumstances, physically separate places of business may be treated as one establishment. For example, if a central administrative unit hires employees, sets their compensation, and assigns them to separate work locations, the separate work sites can be considered part of one establishment. 1

The above considerations are what the Nigerian policy makers and legislators must bear in mind when crafting domestic employment equity law and policy.

\subsection{Equal Pay Enforcement in India}

Article 39 (c) of the Constitution of India provides for Directive Principles of State Policy. This aims for equitable distribution of resources of production among all citizens. It also aims to prevent the concentration of wealth in the hands of a few. One such principle is 'Equal Pay for Equal Work.' As the name itself suggests, its purpose is to ensure that individuals who are doing an equal amount of work shall be entitled to equal remuneration. The term 'equal pay' includes basic salary, and also other benefits, such as bonuses and allowances.

Based on rulings of courts pertaining to interpretation of articles from the Constitution of India, here are some real life case studies: In a landmark case, Randhir Singh $v$ Union of India ${ }^{2}$ the court held that although equal pay for equal work is not regarded as a fundamental right, it is a constitutional goal as per the provisions of Articles 14, 16 and 39(c). Article 14 of the Constitution of India provides citizens with the right to equality before law. Under Article 16, a person is entitled to equality of opportunity in matters of public employment. In the abovementioned case, the court held that the principle of equal pay for equal work can be enforced by courts in cases of unequal pay scales based on unreasonable classifications.

In another significant case, F.A.I.C and C.E.S v Union of India, ${ }^{3}$, it was held by the court that the duties performed by a stenographer of grade I were much higher as compared to a stenographer of subordinate officers. Therefore, the different pay scales fixed for them were justified. Similarly, in State of Haryana v Rajpal Sharma, ${ }^{4}$ the court held that the teachers employed in private schools aided by the State Government are entitled to equal remuneration as that of teachers working in government school. In another milestone case, State of Haryana $v$ Tilak Raj ${ }^{5}$ the court held that the daily wagers who were employed in Haryana Roadways are not covered under the principle of equal pay for equal work. It was held that this principle is only applicable to a person who is employed at a definite post. The daily wagers are not entitled to the same remuneration as regular and permanent employees, as the wagers hold no definite posts.

\section{Equal Pay Enforcement in Nigeria: The Way Forward}

Two major issues will be raised in this section regarding the enforcement of equal Pay in Nigeria. The first is how to create a pay structure to reward work based on its value to the organization. This speaks to the problem of assessing the worth of labour. This is no easy task and requires professional help. The second issue is as regards the paucity of gender discrimination law and policy in Nigeria.

In the Nigerian public sector, a traditional pay structure is used, wherein employees are routinely promoted after a period of time irrespective of the quality of their output provided only that they have not received official queries for a given number of times. Aside from promotions, staff salaries also benefit from small annual increments. The downside of this traditional pay structure is that a civil servant can drift upwards until he/she reaches the top of the pay scale. This does not ensure that the person in question is working to full capacity. Without some form of appraisal scheme or other performance management scheme the long term pay spine allows the individual. The employer who is looking for efficiency may thus be hampered by a pay structure.

Modern pay schemes therefore seek to reward efficiency and not just longevity of service. The traditional pay structure is fast being phased out in the private sector. A private sector employer is interested in seeing the qualitative and quantitative output a worker can bring to the job. ${ }^{6}$ An assessment of competencies which can be brought to the work is therefore of increasing importance in pay and reward structures. Workers or employees who drift through their day bringing very little to their employment are not of equal value to the employer. The equal pay principle is based around an evaluation of work. Equal pay for equal work, equal pay for work of equal value, or work related as equivalent in a job evaluation scheme requires an analysis of work done. ${ }^{7}$

The second issue raised in this discourse is the paucity of equal pay legislation in Nigeria. The only direct mention of the concept is in chapter two of the Constitution which provides that 'in furtherance of the social order, the State shall direct its policy towards ensuring that there is equal pay for equal work without discrimination on

\footnotetext{
${ }^{1} \mathrm{http}: / /$ www.eeoc.gov/laws/types/equalcompensation.cfm accessed 14/7/20.

${ }^{2}$ AIR 1982 SC 879,

3 (1998) 3 SCC 91

${ }^{4}$ AIR 1997 SC 449

${ }^{5}$ AIR 2003 SC 2658

${ }^{6}$ Ikeanyibe M.O., (2009), Principles and Practice of Public Personnel Administration A Nigerian Perspective, (Onitsha: Perfect Image) 124.

${ }^{7}$ Ibid.
} 


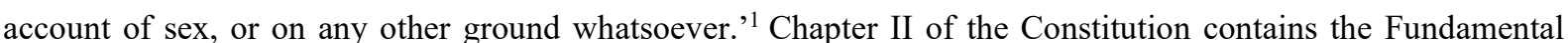
Objectives and Directive Principles of State Policy which according to S.6(6)(c) are not legally enforceable by any court in Nigeria. They are policies which the Government aspires to, guiding principles and not binding laws.

Even though Chapter II of the Constitution is more a body of recommendations than of laws, an active judiciary may still require employers to apply the equal pay policy contained therein, especially as it is in line with international labour standards. This was the attitude of the Supreme Court of India in the landmark case of Randhir Singh $v$ Union of India. ${ }^{2}$ In this case, although Article 39 (c) of the Indian Constitution which espouses equal pay for equal work is not justiciable, being also a directive principles of state policy, the court nonetheless held that the principle of equal pay for equal work can be enforced by courts in cases of unequal pay scales based on unreasonable classifications. The Nigerian Courts are encouraged to embrace the type of judicial activism displayed by Indian courts in such matters.

The National Assembly in 2006, vide the National Industrial Court Act (NIC Act) established the National Industrial Court, vesting it with exclusive jurisdiction over all labour related matters. ${ }^{3}$ By the Third Alteration to the 1999 Constitution, ${ }^{4}$ the NIC was repositioned within the structure of the judiciary and as one of the superior courts of record under section 6 of the 1999 Constitution. Another major effect of the Third Alteration Act on the NIC was the introduction and recognition of the concept of unfair labour practices and unhindered application of international best practices, including international conventions, treaties and protocols that relate to employment/labour issues which are ratified by Nigeria..$^{5}$ This enlarged jurisdiction of the NICN has led to the emergence of decisions which have advanced employment equity in Nigeria. For instance, in Ejieke Maduka v. Microsoft Nigeria Limited \& ors, ${ }^{6}$ the NICN found the defendant liable for sexual harassment which amounted to a breach of an employee's fundamental right to dignity of person as stipulated in several international instruments. ${ }^{7}$ In Folarin Oreka Maiya v. The Incorporated Trustees of Clinton Health Access initiative, Nigeria \& 2 ors (2012), ${ }^{8}$ unfair dismissal on the basis of pregnancy also cost the defendant heavy damages. These cases address labour law issues on which the labour law jurisprudence has been silent for decades. It is extremely disappointing that Nigeria's Labour Act does not have specific provisions on workplace sexual harassment and other employment equity provisions. Nothing cries for the repeal of this outdated law as this omission.

\section{Conclusion and Recommendations}

In the past few decades, the percentage of women in paid employment in Nigeria has significantly increased due to women's participation in higher education. However distinct differences exist in the types of occupation entered by women and men. Women get lower paid jobs in personal services and sales, clerical and administrative positions. Professions like law, medicine and accountancy have also witnessed increased female engagement but there has not been a corresponding women movement into the sciences, engineering, ICT and the skilled trades. ${ }^{9}$ To date, women are scarcely found in managerial positions overall, they make up only $32 \%$ of managers and senior officials in the West and $17 \%$ in Africa. ${ }^{10}$ We only see women dominate in traditional humanist professions like nursing, teaching, catering etc, which are poorly remunerated.

The ILO has shed a brilliant beacon of light to guide national legislation and policy to employment equity. For workers to develop their potential to the full and to reap the economic rewards they deserve, equality and nondiscrimination must not only be legislated, they must be imbibed into the nation's psyche. The Equal Remuneration Convention, 1951 (No. 100), recognized the principle of equal remuneration for men and women for work of equal value. It also paved the way for the acknowledgement that equality in pay could not be achieved without the elimination of discrimination in all areas of employment.

The Discrimination (Employment and Occupation) Convention (No. 111) and Recommendation (No. 111), 1958, requires the elimination of both direct and indirect discrimination, and also requires that the underlying causes of inequalities which result from deeply entrenched discrimination, complex social patterns, institutional structures, policies and legal constructs, be addressed, including through the implementation of proactive measures,

\footnotetext{
1999 Constitution s.17(3)(e).

${ }^{2}$ supra

${ }^{3}$ National Industrial Court Act Cap No 1 of 2006.

${ }^{4}$ Constitution of the Federal Republic of Nigeria (Third Alteration) Act, 2010 which took effect from 4th March, 2011.

${ }^{5}$ section 7(6) of the National Industrial Court Act. See also B.B. Kanyip, "Advancing the Frontiers of Employment Law and Practice in Nigeria through Law Reporting: Nigerian Labour Law Reports as a Case Study" A Discussion Paper presented at the First Colloquium on Employment Law and Practice in honour of Enobong Etteh, to mark his 50th birthday which held at Quad.7 Event Centre, 171 Gbagada Express Way, Lagos on 31 st January, 2015.

${ }^{6}$ Unreported Suit NICN/LA/492/2012, 19 December 2013. See also Aero Contractors Co of Nigeria Limited v National Association of Aircrafts Pilots and Engineers [2014] 42 NLLR (Pt 133) 664 NIC.

${ }^{7}$ ILO Discrimination (Employment and Occupation) Convention, 1958 (No. 111), Convention on the Elimination of All Forms of Discrimination against Women (CEDAW)1979 and African Charter on Human and Peoples' Rights, 1981.

${ }^{8}$ [2012] 27 NLLR (PT. 76) 110 NIC.

${ }^{9}$ ILO, Women and Work Commission, 2015.

${ }^{10}$ Ibid.
} 
with the aim of achieving substantive equality. ${ }^{1}$ Convention No. 111 addresses all forms of discrimination in the context of the world of work on the basis of specific grounds such as race, colour, sex, religion, political opinion, national extraction and social origin with the possibility of extending protection to tackle discrimination on the basis of other criteria such as family responsibilities.

Discrimination based on pregnancy and maternity are discriminatory because they affect only women. For this reason, the Maternity Protection Convention, 2000 (No. 183) explicitly recognized that maternity protection is a precondition for gender equality and for non-discrimination in employment and occupation. Sex discrimination refers not only to distinctions based on biological characteristics but also to unequal treatment arising from socially constructed roles, stereotypes and responsibilities assigned to a particular sex, including the idea that only women should take on primary responsibility for unpaid care work. The Workers with Family Responsibilities Convention, 1981 (No. 156) and the Domestic Workers Convention, 2011 (No. 189), are also significant in promoting equality and eliminating discrimination against women, thereby reducing gender gaps in employment.

Convention No. 111 recognizes that gender equality in the world of work cannot be achieved unless genderbased discrimination prior to entry into the labour market is addressed. Biases can begin very early in life, sometimes in subtle ways, and start trajectories of inequality that become increasingly difficult and costly to resolve. Government should very deliberately develop and enforce policies across the lifecycle that are capable of levelling the playing field. During childhood and youth, policy actions can tackle inequalities through education and training. Education systems can challenge gender stereotypes through revised curricula which depict women in the workforce rather than always in the kitchen. Skills-acquisition programs can also make a huge difference for those outside the educational sector. For women of productive age, government actions should focus on eliminating legal and social barriers to women getting paid work such as removing unequal status provisions, allowing and encouraging women's ownership and joint-titling of land; enforcing equitable inheritance laws and applying nondiscrimination principles to customary laws. For the elderly, governments can support equitable oldage labor regulations combined with appropriate social and welfare protection. In developing countries such as Nigeria where the old-age dependency ratio is extremely high, there are increased elderly care responsibilities for working age women.

To achieve a better future for women at work, legislation must be enacted to incorporate the salubrious provisions of the above stated ILO Conventions. Until this is done, the buck rests with the National Industrial Court (NIC) to continue to enforce these international instruments.

\section{References}

Adesomoju A, (2012) 'LEPAD Sues NDLEA for Gender Discrimination', Punch Newspaper, http://www.punchng.com/news/ledap-sues-ndlea-for-gender-discrimination/

Becker G, (1975) The Economics of Discrimination, (Chicago: University of Chicago Press, 1957), p.27

De Henau, et al, (2018) Women, Employment and Earnings (WBG Briefing: 2018); United Kingdom Government Equalities Office.

Enfield S, (2019) Gender Roles and Inequalities in the Nigerian Labour Market, (United Kingdom: Institute of Development Studies) May 2019.

European Institute for Gender Equality, "Equal Pay for Equal Work," https://eurogender.eige.europa.eu/posts/equal-pay-equal-work.

Farrel W., (2006) 'Are Women Earning More Than Men?' Forbes Newspaper, May 12, 2006, www.forbes.com/2006, accessed on 26/07/20.

Fernandez A, (2015) Humanity Divided: Confronting Inequality in Developing Countries, UNDP 2015

Hausman R. et al, The Global Gender Gap Index 2012 Report, (Davos: World Economic Forum, 2012), World Development Indicators, 2011 data.

Henderson D.R., (2008) 'How Free Markets Break Down Discrimination' The Freeman, Vol. 58, Issue 3, April 2008.

Ifemeje S.C. and Ikpeze O.V.C., (2012) "Global Trend Towards Gender Equality: Nigeria's Experience in Focus" Vol. 2, No.3 Kuwait Chapter of Arabian Journal of Business and Management Review, 51

Ikeanyibe M.O., (2009), Principles and Practice of Public Personnel Administration A Nigerian Perspective, (Onitsha: Perfect Image) 124.

ILO, (2013), Equal Pay, an Introductory Guide, https://www.ilo.org/global/publications/WCMS_216695/lang-en/index.htm

ILO, (2019), A Quantum Leap for Gender Equality: for a Better Future of Work for All, (Geneva: ILO).

ILO, Equal Remuneration for Work of Equal Value, https://www.ilo.org/global/topics/wages/minimumwages/rates/WCMS_433906/lang--en/index.htm,

${ }^{1}$ ILO 2018. 
Jones L, (2019) “Women's Progression in the Workplace”, Global Institute for Women's Leadership, (London: Kings College).

Killingsworth, M.R., (1990), The Economics of Comparable Worth. Kalamazoo, MI: W.E. Upjohn Institute for Employment Research.

L Suraj (2012) 'Female Cops Can Now Marry without Permission' Sahara Reporters, $\mathrm{http}$ //saharareporters.com/news-page/nigerian-court-nullifies-police-marriage-permit-female-cops-cannow-marry-without-permission

Lewis, J.J., (2020) "Comparable Worth: Equal Pay for Work of Equal Value." ThoughtCo, Feb. 11, 2020, thoughtco.com/comparable-worth-pay-equity-3529471.

Maclagan P, (1998), Management \& Morality, (Thousand Oaks, IL: Sage Press), p. 33

Ontario Ministry of Labour, Training and Skills Development, 'Equal Pay for Equal Work' https:/www.ontario.ca/document/your-guide-employment-standards-act-0/equal-pay-equal-work,

Peterson T and Morgan L.A., (1995) 'Separate and Unequal: Occupation-Establishment Sex Segregation and the Gender Wage Gap’ American Journal of Sociology 101, 329-365, (Chicago: University of Chicago Press) https://www.jstor.org/stable/2782431

Singh S and Samara R., (1996) "Early Marriage Among Women in Developing Countries.” 22 (4) International Family Planning Perspectives: 148-175.

Tennant M., (2009) 'The Justice of Pay Discrimination', www.LewRockwell.com, accessed on 26/7/20.

UNDP, (2010) Human Development Report 1995, (New York: Oxford University Press).

\section{The Author}

Chineze Sophia Ibekwe is the Head, Department of Commercial and Property Law in Nnamdi Azikiwe University, Nigeria. Her research interests include employment discrimination, labour law, intellectual property and the environment. She is a legal practitioner with consummate experience in business, real estate law and commercial dispute resolution. She is affiliated to the Nigerian Institute of Chartered Arbitrators (NICArb) and the Institute of Chartered Mediators and Conciliators (ICMC). She is a vocal advocate for human and minority rights under the aegis of the Federation of Female Lawyers (FIDA) Nigeria. She has an LL.B from the University of Nigeria Nsukka with LL.M and PhD degrees from the Nnamdi Azikiwe University. 